\title{
Occurrence of tick-borne pathogens in dogs in a coastal region of the state of Ceará, northeastern Brazil
}

\author{
Ocorrência de patógenos transmitidos por carrapatos em cães em uma região \\ litorânea do estado do Ceará, nordeste do Brasil
}

\begin{abstract}
Arícia Débora Vasconcelos Fonsêca'; Lorena Mayana Beserra de Oliveira1* (1D;
Felipe Rodrigues Jorge ${ }^{1}$; Ramuelly Olinda Cavalcante ${ }^{1}$; Claudia Maria Leal Bevilaqua ${ }^{1}$; Francisco José Maia Pinto²; Jessica Maria Leite dos Santos3; Bruno Marques Teixeira33; Ana Kétylla Ponte Prado Rodrigues ${ }^{3}$; Gissandra Farias Braz;3; Geysa Almeida Viana3; Edmara Chaves Costa4; Maria Carolina de Azevedo Serpa5;

Bárbara Conte Weck ${ }^{5}$; Marcelo Bahia Labruna ${ }^{5}$

'Laboratório de Doenças Parasitárias, Programa de Pós-graduação em Ciências Veterinárias, Universidade Estadual do Ceará - UECE, Fortaleza, CE, Brasil

${ }^{2}$ Centro de Ciências da Saúde, Universidade Estadual do Ceará - UECE, Fortaleza, CE, Brasil

${ }^{3}$ Centro de Ciências da Saúde, Centro Universitário INTA - UNINTA, Sobral, CE, Brasil

${ }^{4}$ Instituto de Ciências da Saúde, Universidade da Integração Internacional da Lusofonia Afro-Brasileira - UNILAB, Redenção, CE, Brasil ${ }^{5}$ Departamento de Medicina Veterinária Preventiva e Saúde Animal, Faculdade de Medicina Veterinária e Zootecnia, Universidade de São Paulo - USP, São Paulo, SP, Brasil
\end{abstract}

\begin{abstract}
How to cite: Fonsêca ADV, Oliveira LMB, Jorge FR, Cavalcante RO, Bevilaqua CML, Pinto FJM, et al. Occurrence of tick-borne pathogens in dogs in a coastal region of the state of Ceará, northeastern Brazil. Braz J Vet Parasito/ 2022; 31(1): e021321. https:// doi.org/10.1590/S1984-29612022010
\end{abstract}

\begin{abstract}
The aim of this study was to determine the occurrence of tick-borne pathogens (Ehrlichia canis, Babesia vogeli, Hepatozoon spp. and Rickettsia spp.) in dogs in Vila de Jericoacoara, coastal region of Ceará, Brazil. Blood samples were collected from 153 animals and analyzed using molecular and serological methods. Sixty animals were found to be infected or exposed to at least one of the pathogens studied. Babesia vogeli was the most prevalent pathogen (15\%), followed by E. canis (13.7\%) and Hepatozoon spp. (11.8\%), which was identified as Hepatozoon canis through sequencing. Twenty dogs (13\%) were seroreactive to Rickettsia spp. Rhipicephalus sanguineus sensu lato was observed on $11.8 \%$ of the animals. There were associations between age ( $<3$ years old) and positivity for $B$. vogeli, and between habitation (stray dogs) and positivity for $H$. canis. There were also associations between anemia and infection with $\mathrm{H}$. canis, and between leukopenia and exposure to Rickettsia spp. No association was detected between clinical alterations and infection with or exposure to the pathogens studied. The results confirmed that pathogens of veterinary importance are circulating in northeastern Brazil and showed that dogs are exposed to Rickettsia species with zoonotic potential, thus indicating a need for vector control measures.
\end{abstract}

Keywords: Babesia vogeli, Hepatozoon canis, Ehrlichia canis, Rickettsia spp., epidemiology.

\begin{abstract}
Resumo
O objetivo deste estudo foi determinar a ocorrência de patógenos transmitidos por carrapatos (Ehrlichia canis, Babesia vogeli, Hepatozoon spp. e Rickettsia spp.) em cães na Vila de Jericoacoara, região costeira do Ceará, Brasil. Amostras de sangue foram coletadas de 153 animais e analisadas por métodos moleculares e sorológicos. Sessenta animais foram encontrados infectados ou expostos a pelo menos a um dos patógenos estudados. Babesia vogeli foi o patógeno mais prevalente (15\%), seguido por E. canis (13,7\%) e Hepatozoon spp. (11,8\%), que foi identificado como Hepatozoon canis por sequenciamento. Vinte cães (13\%) foram sororreativos à Rickettsia spp. Rhipicephalus sanguineus sensu lato foi observado em $11,8 \%$ dos animais. Houve associações entre idade (<3 anos) e positividade para B. vogeli, e entre habitação (cães de rua) e positividade para $H$. canis. Também houve associações entre anemia e infecção por H. canis, e entre leucopenia e exposição a Rickettsia spp. Não foi detectada associação entre alterações clínicas e infecção ou exposição aos patógenos estudados. Os resultados confirmaram que patógenos de importância veterinária estão circulando no nordeste do Brasil e mostraram que cães estão expostos a espécies de Rickettsia com potencial zoonótico, indicando a necessidade de medidas de controle do vetor.
\end{abstract}

Palavras-chave: Babesia vogeli, Hepatozoon canis, Ehrlichia canis, Rickettsia spp., epidemiologia.

Received December 6, 2021. Accepted January 28, 2022

*Corresponding author: Lorena Mayana Beserra de Oliveira. E-mail: Iorena.mayana@uece.br 


\section{Introduction}

The emergence and reemergence of arthropod-borne diseases has been a challenge for veterinary and human medicine. Arthropods and the infections transmitted by them are expanding their zoogeographical limits due to climate change and increased accessibility to certain environmental niches (Shaw et al., 2001; Han et al., 2016). Common species of tick-borne pathogens include Babesia vogeli, Hepatozoon canis, Ehrlichia canis and Rickettsia spp. of the spotted fever group (SFG). These pathogens cause canine diseases in several geographical regions including tropical areas (Chomel, 2011).

The above-cited tick-borne pathogens can be divided into two groups. The first includes the protozoa $B$. vogeli and H. canis, and the second includes the bacteria E. canis and Rickettsia spp. Babesia vogeli has worldwide distribution and usually gives rise to subclinical infection in adult domestic dogs, although it is potentially fatal in young dogs (Schnittger et al., 2012). Hepatozoon canis is distributed throughout the Old World and in parts of the New World, and domestic dogs infected with this agent present lethargy with mild anemia (Baneth, 2011). Ehrlichia canis is a common pathogen affecting domestic dogs around the world and causes canine monocytic ehrlichiosis, with clinical and hematological abnormalities such as fever, anorexia, vomiting, diarrhea, petechial hemorrhages, anemia and thrombocytopenia (Moreira et al., 2003; Moraes-Filho et al., 2015). Spotted fever group (SFG) rickettsiae are a neglected group of bacteria belonging to the genus Rickettsia, which accounts for a large number of new and emerging infectious diseases with worldwide distribution and can cause serious diseases in humans and animals (Labruna et al., 2009; Oliveira et al., 2016; Robinson et al., 2019).

In many parts of Brazil, there are records of dogs infected by tick-borne pathogens at wide ranges of occurrence and prevalence rates (Saito et al., 2008; Ramos et al., 2010; Spolidorio et al., 2011; Vieira et al., 2011; Costa et al., 2015; Miranda et al., 2014; Rotondano et al., 2015). In contrast, there is a scarcity of data about the epidemiology of tick-borne diseases in the coastal region of northeastern Brazil. Therefore, the aim of the present study was to make the first determination of occurrence rates of B. vogeli, Hepatozoon spp., E. canis and Rickettsia spp. in dogs and their ectoparasites in the municipality of Jijoca de Jericoacoara, located in the coastal region of the state of Ceará, Brazil. Furthermore, this study also investigated the possible epidemiological, clinical and hematological aspects of the diseases caused by these pathogens.

\section{Materials and Methods}

\section{Ethics committee}

The present cross-sectional, descriptive and analytical study was approved by the Ethics Committee on Animal Experimentation at Centro Universitário Inta (UNINTA), state of Ceará, Brazil (protocol number: 2019.07.009-P).

\section{Study area}

This study was conducted in Vila de Jericoacoara ( $2^{\circ} 47^{\prime} 45^{\prime \prime} \mathrm{S} ; 40^{\circ} 30^{\prime} 52^{\prime \prime} \mathrm{W}$ ), which is a village within the municipality of Jijoca de Jericoacoara, state of Ceará (Figure 1), northeastern Brazil. This village is on the shore of the Atlantic Ocean and its other geographical limit is the National Park (PARNA) of Jericoacoara, a conservation unit that has the aims of protecting biodiversity and coastal ecosystems, ensuring the preservation of its natural resources and enabling scientific research, environmental education and ecological tourism (ICMBio, 2021). Vila de Jericoacoara covers an area of $1.1 \mathrm{~km}^{2}$ and its streets are unpaved. Its average annual temperature is $25-35^{\circ} \mathrm{C}$ and it lies within the Caatinga biome, with the vegetation complex of the coastal zone.

\section{Animals}

For this study, dogs living in Vila de Jericoacoara were selected through convenience sampling. This sample totaled 153 animals of both sexes and different ages and breeds. The dogs thus selected participated in an extension project carried out by a trained team from the Centro Universitário INTA (UNINTA) and by the association "Jeri sobre Patas" (Jericoacoara on Paws), between April 2019 and December 2020. This project was aimed towards population management of dogs and cats in the village. The owners of these dogs were made aware of the study objectives and, after agreeing to participate, signed informed consent statements. 


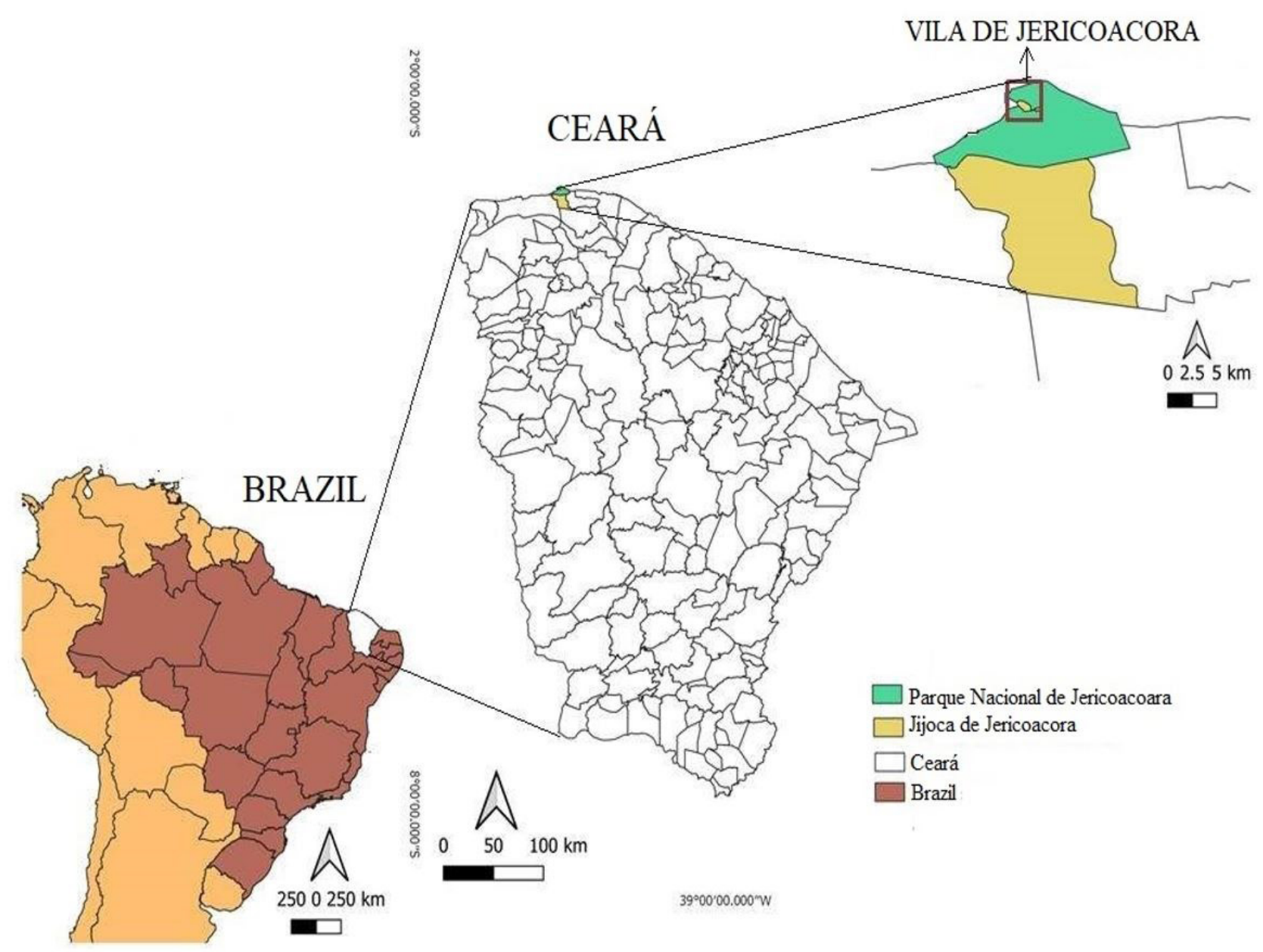

Figure 1. Geographical location of Vila de Jericoacoara, Jijoca de Jericoacoara, Ceará, Brazil.

\section{Data and sample collection}

An epidemiological questionnaire was applied to each dog owner to obtain data for an analysis on factors associated with the outcome regarding the occurrence of infection or exposure to tick-borne pathogens. The possible variables considered in the questionnaire related to gender, breed, age, habitation, street access and presence of ectoparasites. In addition, each dog was physically examined for the presence of clinical signs suggestive of tick-borne diseases, including body condition, lymphadenopathy, weight loss, anorexia and fever. The dog owners were also asked about any recent episodes of vomiting and diarrhea. Body temperatures were measured using a digital thermometer.

Blood samples were collected from the jugular or cephalic vein of each animal. For hematological analyses and molecular tests, the blood was taken into tubes containing EDTA. For serological tests, the blood was stored in tubes without anticoagulant. All the samples were stored on ice and transported to the laboratory on the same day. Both whole-blood and serum (separated by means of centrifugation at 12,000 g for 10 minutes) were stored separately in microtubes at $-20^{\circ} \mathrm{C}$ until laboratory testing.

\section{Collection and identification of ectoparasites}

The ectoparasites found during clinical examinations on the animals were collected using forceps and placed in microtubes containing absolute ethanol. These microtubes were then stored at room temperature until the time of identification. Tick and flea taxonomic identifications were performed using dichotomous keys (Linardi \& Guimarães, 2000; Barros-Battesti et al., 2006; Dubie et al., 2017). 


\section{Extraction and amplification of DNA from Ehrlichia canis, Babesia vogeli and Hepatozoon spp.}

Total DNA was extracted from $200 \mu \mathrm{L}$ of canine whole blood using a commercial DNA extraction kit (Invitrogen ${ }^{\mathrm{TM}}$ PureLink ${ }^{\mathrm{TM}}$ Genomic DNA mini-kit), in accordance with the manufacturer's instructions. It was eluted in $100 \mu \mathrm{L}$ of the elution buffer that accompanied the extraction kit. In order to certify the suitability of this DNA extraction protocol, a random sample of 50 blood extracted DNA samples was tested by a PCR assay targeting a 359-bp fragment of the cyt-B mitochondrial gene of vertebrates (Steuber et al., 2005), which confirmed successful extraction.

All canine DNA samples were analyzed by means of two TaqMan real-time PCR protocols: one specific for E. canis DNA (Doyle et al., 2005) and the other specific for B. vogeli DNA (Peleg et al., 2010). The samples were also tested by means of conventional PCR to detect Hepatozoon spp. (Almeida et al., 2012). The sets of primers and probes used in each reaction are described in Table 1. A positive control, from a dog known to be positive for each pathogen tested, and a negative control consisting of water were included in each technique performed, which are described below. Positive control canine DNA samples consisted of $E$. canis-infected blood from the study of Moraes-Filho et al. (2015), H. canis-infected spleen from the study of Lopes et al. (2019), and B. vogeli-infected blood kindly provided by Prof. Marcos R. André (São Paulo State University, Brazil).

Table 1. Primer pairs and probes used in TaqMan real-time PCR assays, for detecting tick-borne agents.

\begin{tabular}{|c|c|c|c|c|}
\hline $\begin{array}{l}\text { Target agents } \\
\text { (gene) }\end{array}$ & Primers & Primer sequences (5'-3') & (Bp) & Reference \\
\hline Ehrlichia canis & Dsb321 & TTGCAAAATGATGTCTGAAGATATGAAACA & 378 & Doyle et al. (2005) \\
\hline \multirow[t]{2}{*}{ (dsb gene) } & Dsb671 & GCTGCTCCACCAATAAATGTATCYCCTA & & \\
\hline & probe & AGCTAGTGCTGCTTGGGCAACTTTGAGTGAA & & \\
\hline Babesia vogeli & B.c hsp70-F & GTCATCACTGTGCCTGCGTACT & 90 & Peleg et al. (2010) \\
\hline \multirow[t]{2}{*}{ (hsp70 gene) } & B.c hsp70-R & GCATGACGTTGAGACCGGCAAT & & \\
\hline & probe & AGCGCCAGGCCACCAAGGACGCT & & \\
\hline Hepatozoon spp. & HEP2-169 & GGTAATTCTAGAGCTAATACATGAGC & 574 & Almeida et al. (2012) \\
\hline$(18 \mathrm{~S}$ rRNA) & HEP2-718 & ACAATAAAGTAAAAAACAYTTCAAAG & & \\
\hline
\end{tabular}

The real-time PCR for E. canis was used to amplify a 378 base pair (bp) fragment of the $d s b$ gene encoding a disulfide-forming protein, using the Dsb321 and Dsb671 primers and a species-specific probe, as previously described by Doyle et al. (2005). To detect $B$. vogeli, a $90 \mathrm{bp}$ fragment of the $h s p 70$ gene was amplified using the B.c hsp70-F and B.c hsp70-R primers and a species-specific probe, in accordance with the conditions described by Peleg et al. (2010). For these two reactions, data amplification, acquisition and analysis were performed using a multicolor detection system for real-time PCR (7500 Real-Time PCR Systems; Applied BioSystems, Foster City, CA, USA). Samples were considered positive if $\mathrm{Ct}$ values were $<35$. For DNA detection in Hepatozoon spp., the primers HEP2 144-169 and HEP2 743718 were used, which amplified a fragment of about 574 bp of the 18S rRNA gene from Hepatozoon spp., as described in the protocol recommended by Almeida et al. (2012).

\section{Sequencing}

The species of Hepatozoon were identified through generating DNA sequences from PCR amplicons. For this, positive samples were purified using ExoSap (USB) and were sequenced in an automated sequencer (model $A B I$ Prism 310 Genetic; Applied Biosystems / Perkin Elmer, California, USA), in accordance with the manufacturer's protocol, and with the same primers as used in the PCR. Sequences were trimmed for quality and edited by using the SeqMan software (Lasergene; DNAstar, Madison, Wis.). The partial sequences obtained were subjected to BLAST analysis (Altschul et al., 1990) to make inferences regarding the closest similarities to the sequences in GenBank. 


\section{Serological analyses}

Canine serum samples were tested by means of the Immunofluorescent Antibody Test (IFAT) using crude antigens derived from four Brazilian Rickettsia isolates (Rickettsia rickettsii strain Taiaçu, Rickettsia amblyommatis strain Ac37, Rickettsia bellii strain Mogi and Rickettsia felis strain Pedreira), as previously described (Labruna et al., 2007). Briefly, the canine serum samples were serially diluted in phosphate-buffered saline (PBS), in twofold increments from $1 / 64$ to $1 / 2048$, and were instilled on glass slides coated with the antigens. A commercial fluorescein isothiocyanate-labeled anti-dog IgG (Sigma ${ }^{\circledR}$, St Louis, MO, USA) was used as a secondary antibody. On each slide, a known non-reactive canine serum (negative control for all antigens tested) and a known reactive canine serum (positive control for all antigens tested) were tested at 1/64 dilution. These sera were from the study of Costa et al. (2017). For each tested serum, the endpoint titer reacting with each Rickettsia antigen was determined. Serum that reacted to a Rickettsia species with an endpoint titer at least four times higher than the endpoint titers for the other Rickettsia species was considered homologous to the first Rickettsia species or to a very close genotype, as previously reported (Labruna et al., 2007).

\section{Statistical analysis}

The data were tabulated in LibreOffice version 7.1.0.3 and analyzed in the Statistical Package for Social Sciences (SPSS) for Windows, version 23. In describing the data, absolute and percentage frequencies were used for qualitative variables. In the inferential analysis, the Wald chi-square test or likelihood ratio was used to verify associations between independent and dependent variables. Furthermore, Poisson regression with robust estimation was used to determine the adjusted model, with the respective prevalence ratio (PR) and 95\% confidence intervals. For the unadjusted model, variables with $p<0.2$ were used. The significance level of the tests was $5 \%$.

\section{Results}

Among the 153 canine blood samples evaluated, 60 (39.2\%) yielded signs of infection with at least one of the four pathogens studied. Considering the molecular tests, B. vogeli was detected in 23 (15\%), E. canis in 21 (13.7\%) and Hepatozoon spp. in 18 (11.8\%) of the dogs. Six of the 18 samples that tested positive for Hepatozoon spp. were selected for DNA sequencing, in view of the higher intensity of bands obtained through agarose gel electrophoresis. In an analysis on these six sequences using BLAST, all of them showed $100 \%$ similarity to $H$. canis detected in domestic dogs in different countries (KJ513193, KJ513198 and KF621083), and also in the northeastern region of Brazil (MG772658). The single haplotype of $H$. canis $18 \mathrm{~S}$ rRNA partial sequences generated in this study was deposited in GenBank under the accession number OL518910.

Anti-Rickettsia spp. antibodies were detected in 20 dogs (13\%), with endpoint titers ranging from 64 to 2048 (Table 2). Eleven of these 20 animals presented $R$. amblyommatis as a probable homologous antigen (PHA), for which the endpoint titers were four times greater than the endpoint titers shown for the other four Rickettsia species. These 11 animals might have been exposed to $R$. amblyommatis or a very closely related genotype.

Among the 60 infected or exposed animals, 53 were positive for the pathogens investigated by means of molecular detection, among which nine (16.9\%) had coinfections in the following combinations: five dogs (55.5\%) were coinfected with $E$. canis and $H$. canis, three (33.3\%) with E. canis and B. vogeli and one (11.1\%) with B. vogeli and $H$. canis.

Parasitism due to ticks was observed in $18(11.8 \%)$ of the dogs. All the ticks collected were identified as Rhipicephalus sanguineus sensu lato (s.l.). A total of 49 specimens were found: 19 females, 16 males and 11 nymphs. There was an average of 2.72 ticks/dog, with a range from 1 to 7 ticks per animal. Seven animals that were infected or exposed to tick-borne pathogens (7/60) were infested by ticks. In addition, the flea Ctenocephalides felis felis was observed on three (2.0\%) dogs. Regarding the responses to the questionnaire about observation of ectoparasites on dogs by their owners, $30(19.6 \%)$ of the responses were positive. The owners indicated that $29(19 \%)$ of the animals were parasitized by ticks and that five (3.3\%) were infested with fleas.

The analysis on possible factors associated with positivity for B. vogeli, Hepatozoon spp. and $E$. canis and seropositivity for Rickettsia spp. is shown in Table 3. None of the variables studied was associated with positivity for E. canis or with seropositivity for Rickettsia spp. ( $p>0.05)$. For infection by B. vogeli, the following variables were selected: breed $(p=0.156)$ and age $(p=0.009)$. For infection by Hepatozoon spp., breed $(p=0.122)$, age $(p=0.059)$ and habitation ( $p=0.010$ ) were selected. After Poisson regression, only age ( $<3$ years old) was confirmed to be 
Table 2. Results from Immunofluorescent Antibody Test (IFAT) against four Rickettsia species, among serum samples from dogs in Vila de Jericoacoara, Jijoca de Jericoacoara, Ceará, Brazil, 2020.

\begin{tabular}{|c|c|c|c|c|c|}
\hline \multirow[b]{2}{*}{ Animals } & \multirow[b]{2}{*}{ Rickettsia rickettsii } & \multicolumn{3}{|c|}{ Endpoint titers for rickettsial antigens } & \multirow[b]{2}{*}{ PHA } \\
\hline & & $\begin{array}{c}\text { Rickettsia } \\
\text { amblyommatis }\end{array}$ & Rickettsia bellii & Rickettsia felis & \\
\hline C-08 & - & 256 & - & - & R. amblyommatis \\
\hline C-09 & - & 2048 & - & - & R. amblyommatis \\
\hline $\mathrm{C}-10$ & 256 & 256 & 128 & - & - \\
\hline C-12 & 256 & 256 & - & - & - \\
\hline$C-24$ & - & 512 & - & - & R. amblyommatis \\
\hline C-29 & 256 & 512 & - & - & - \\
\hline$C-34$ & 512 & 1024 & - & - & - \\
\hline C-39 & - & 64 & - & - & - \\
\hline C-40 & - & 64 & - & - & - \\
\hline$C-60$ & - & 64 & - & - & - \\
\hline$C-62$ & - & 1024 & - & - & R. amblyommatis \\
\hline C-63 & - & 128 & - & - & - \\
\hline C-64 & - & 256 & - & - & R. amblyommatis \\
\hline C-66 & - & 256 & - & - & R. amblyommatis \\
\hline$C-70$ & - & 256 & - & - & R. amblyommatis \\
\hline$C-88$ & - & 256 & - & - & R. amblyommatis \\
\hline C-94 & - & 1024 & - & 64 & R. amblyommatis \\
\hline C-118 & - & 256 & - & - & R. amblyommatis \\
\hline C-119 & - & 256 & - & - & R. amblyommatis \\
\hline C-134 & - & 64 & - & - & - \\
\hline
\end{tabular}

associated with infection by $B$. vogeli $(\mathrm{PR}=2.95 ; 95 \% \mathrm{Cl} 1.23$ to $7.07 ; \mathrm{p}=0.009)$; and only outdoor habitation (stray dogs) with infection by Hepatozoon spp. ( $P R=4.0 ; 95 \% \mathrm{Cl} 1.7$ to $10.0 ; p=0.010)$.

At the time of physical examination, it was observed that some animals that had been infected or exposed to the pathogens studied presented clinical alterations suggestive of tick-borne diseases, including lymphadenopathy (23/60), fever (8/60), pale mucous membranes (5/60), diarrhea (3/60), anorexia (1/60) and weight loss (1/60). However, there was no significant association between the clinical alterations and infection by $E$. canis, $B$. vogeli or Hepatozoon spp., or exposure to Rickettsia spp. $(p>0.05)$.

Table 4 shows analyses on the hematological alterations of the animals studied that were positive for $B$. vogeli, Hepatozoon spp. and E. canis and seropositive for Rickettsia spp. There were significant associations between anemia and infection by Hepatozoon spp. ( $P R=2.14 ; 95 \% \mathrm{Cl} 1.16$ to 3.95; $\mathrm{p}=0.036)$ and between leukopenia and presence of anti-Rickettsia antibodies ( $P R=8.61 ; 95 \% \mathrm{Cl} 1.60$ to $46.21 ; \mathrm{p}=0.033$ ).

\section{Discussion}

This study showed that dogs in Vila de Jericoacoara were infected with B. vogeli, E. canis and H. canis or presented anti-Rickettsia spp. antibodies. Although these pathogens had previously been reported infecting dogs in other states in Brazil (Saito et al., 2008; Ramos et al., 2010; Spolidorio et al., 2011; Vieira et al., 2011; Costa et al., 2015; 


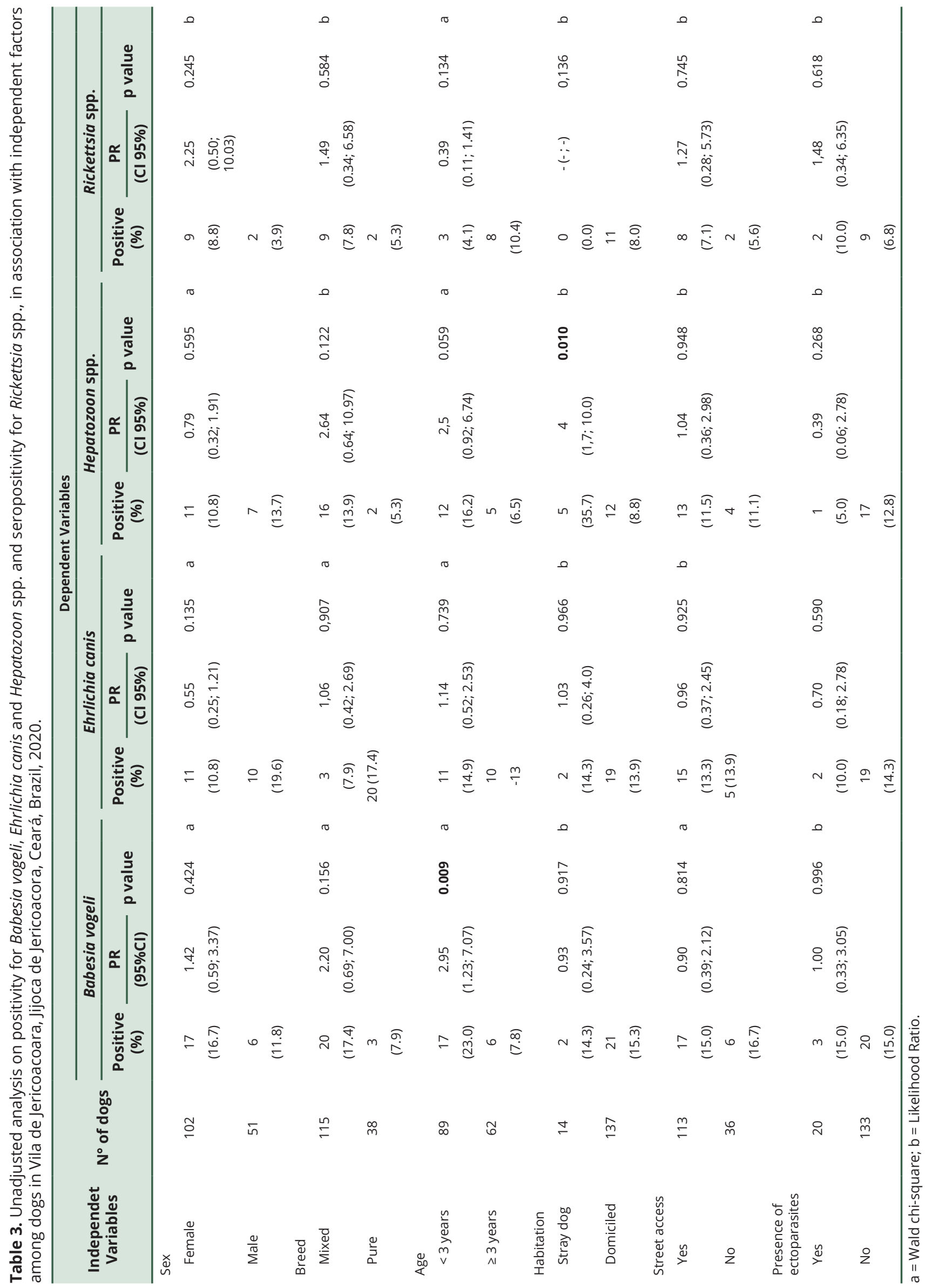




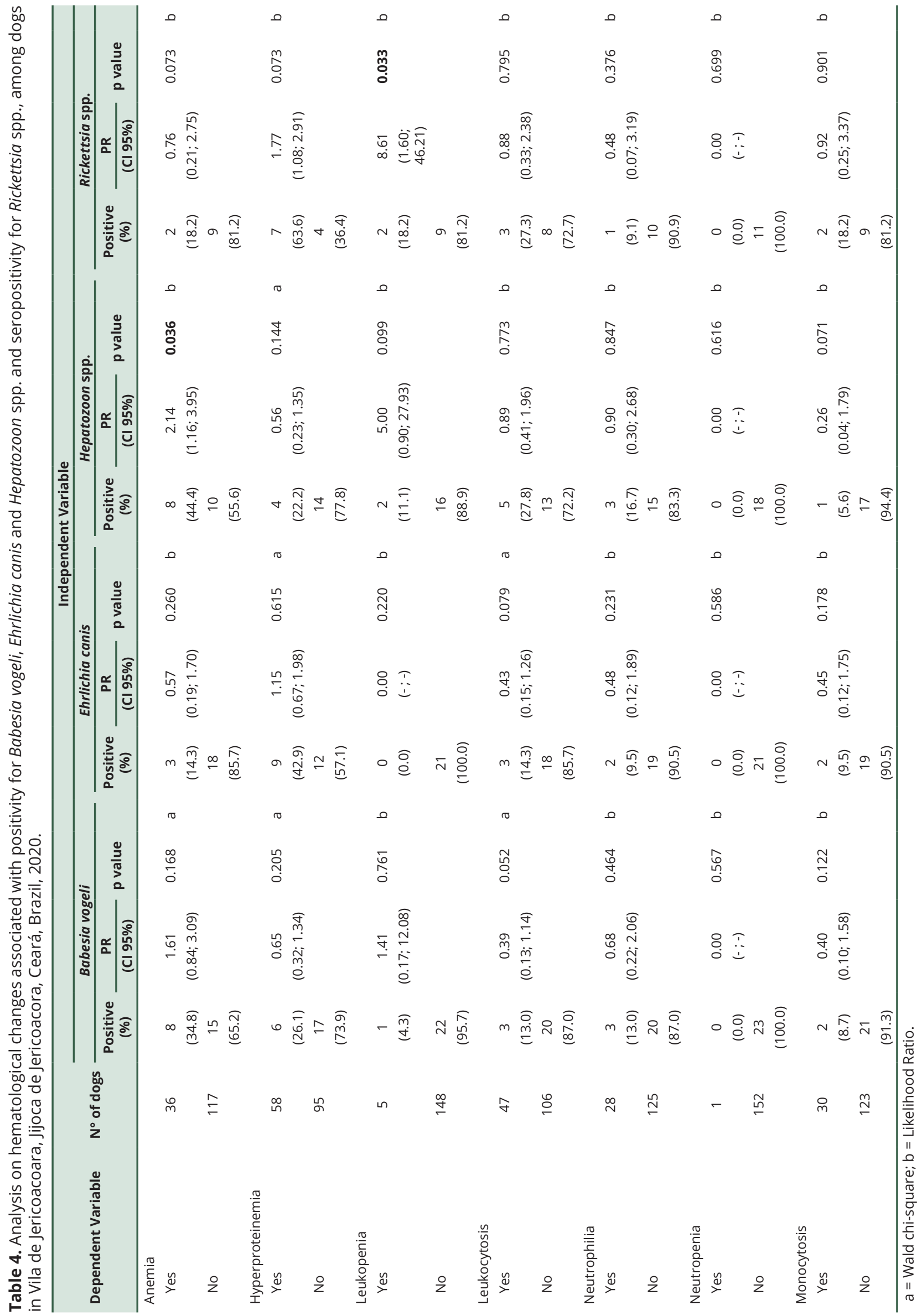




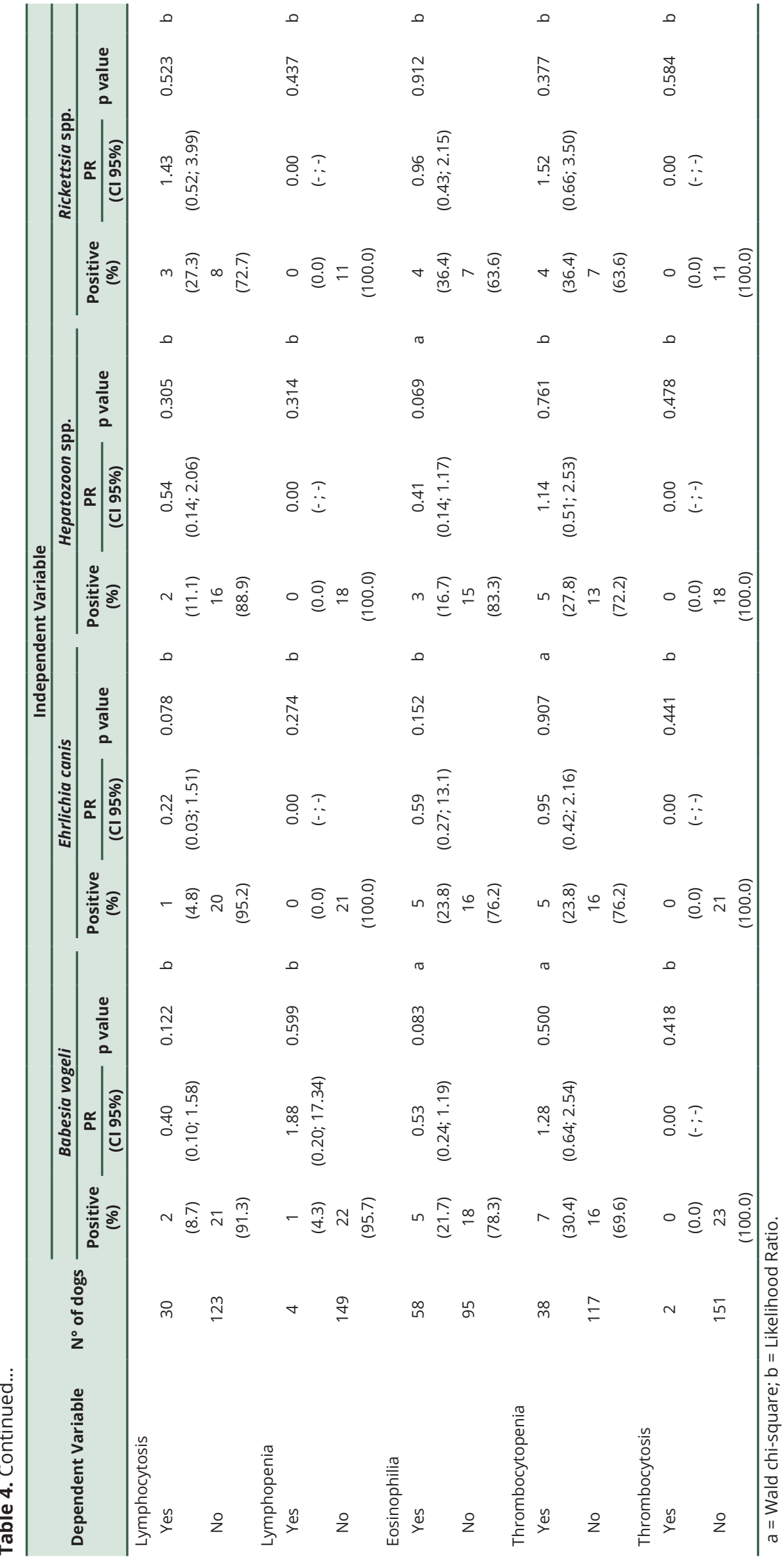


Miranda et al., 2014; Rotondano et al., 2015, 2017; Lopes et al., 2019; Oliveira et al., 2020), data relating to Ceará were very scarce, and were mainly from the coastal region. Recently, $R$. rickettsii, $R$. amblyommatis and $E$. canis were reported infecting dogs in the National Forest (FLONA) of Araripe-Apodi, in the municipality of Crato, state of Ceará (Oliveira et al., 2020). However, there had not been any previous reports of $H$. canis and $B$. vogeli in dogs in this state.

The occurrence of infection by tick-borne pathogens in dogs observed in this study reflected problems in sanitary management in the region studied. Certain factors may have favored transmission of ectoparasites among animals. Figueredo et al. (2017) assessed exposure to vector-borne pathogens among privately owned dogs that were living in four Brazilian cities, in two states (Pernambuco and Minas Gerais) and in the Federal District. Overall, 69.3\% of the dogs were positive for at least one of the pathogens tested (Anaplasma spp., Ehrlichia spp., Babesia spp., Leishmania spp. and Dirofilaria immitis), and $66.8 \%$ of them were positive for two or more pathogens. According to these authors, there is a need to establish a relationship between the socioeconomic status of the owners and the level of exposure to ectoparasites and the pathogens that they transmit. In our study, the dog owners selected had low income levels.

In the present study, $R$. sanguineus s.l. was the only tick species found. Interestingly, none of the known tick vectors for the SFG in Brazil were detected on these animals. In the municipality of Patos, state of Paraíba, also in northeastern Brazil, $R$. sanguineus s.l. was also the only species found among the dogs. Ticks of the genus Amblyomma were not detected (Tanikawa et al., 2013). According to these authors, environmental factors such as the semiarid climate and the typical xeric forest of the Caatinga biome may have had an association with the absence of tick vectors of the genus Amblyomma in the study region. On the other hand, Oliveira et al. (2020) proved that dogs in the FLONA of Araripe-Apodi were infested with R. sanguineus s.l., Amblyomma parvum and C. felis felis; and that specimens of A. parvum and C. felis felis were infected with Rickettsia spp. Parasitism by other tick species in dogs in Vila de Jericoacoara should not be ruled out, given the presence of anti-R. amblyommatis antibodies in the animals studied. Moreover, this village is surrounded by the National Park of Jericoacoara, which forms a domestic-wild animal interface with large diversity of animals and ectoparasite species.

Rickettsia amblyommatis has been reported infecting Amblyomma auricularium, A. parvum (Saraiva et al., 2013; Lugarini et al., 2015; Oliveira et al., 2020), Amblyomma longirostre (Ogrzewalska et al., 2011; Lugarini et al., 2015; McIntosh et al., 2015), Amblyomma cajennense sensu stricto (ss) (Costa et al., 2017), Amblyomma pseudoconcolor (Silva et al., 2018) and Amblyomma varium (Lugarini et al., 2015) in northeastern Brazil. Although the pathogenicity of $R$. amblyommatis to humans has not yet been proven, some cases of Rocky Mountain spotted fever in the United States may have been caused by this bacterium (Apperson et al., 2008). Studies have demonstrated that dogs were naturally infected with $R$. amblyommatis in northeastern Brazil (Costa et al., 2017) and in the United States (Barrett et al., 2014). Saraiva et al. (2013) confirmed the vector competence of $A$. auricularium for $R$. amblyommatis. Considering the exposure to $R$. amblyommatis among the dogs studied here, it can be suggested that ticks of the genus Amblyomma were present in Vila de Jericoacoara. Furthermore, C. felis felis fleas were previously found to be infected with R. felis in Ceará (Oliveira et al., 2020). However, the dogs tested in the present study did not show titers that would correspond to exposure to the species R. felis, although C. felis felis fleas were found on three animals.

Our study was the first to confirm the occurrence of $B$. vogeli in the state of Ceará through molecular tests. The results found demonstrated a high rate of occurrence, compared with other recent reports in northeastern Brazil. The molecular prevalence of canine babesiosis in this region of Brazil has ranged from $0.9 \%$ to $10 \%$ (Silva et al., 2012; Rotondano et al., 2015; Costa et al., 2015; Silva et al., 2016; Braga et al., 2019).

The occurrence of infection by $E$. canis in the canine population of Vila de Jericoacoara was similar to that found in other studies conducted in the northeastern region of Brazil. Rotondano et al. (2017) found the molecular occurrence of E. canis $8.9 \%$ among dogs in an urban area in the state of Paraíba. In this region of Brazil, the molecular ocurrence of $E$. canis infection has ranged from 1.7\% to 25\% (Tanikawa et al., 2013; Costa et al., 2015; Rotondano et al., 2015, 2017; Dantas-Torres et al., 2018).

The occurrence of infection by Hepatozoon spp. of $11.8 \%$ (confirmed as H. canis in six dogs) among the dogs in Vila de Jericoacoara corroborated previous data on the circulation of this parasite in northeastern Brazil. The rates have ranged from 0.49\% in Pernambuco to 10\% in Rio Grande do Norte (Ramos et al., 2010; Bernardino et al., 2016; Lopes et al., 2019). The occurrence rate can range from $8.6 \%$ to $100 \%$ in the southeastern region (O'Dwyer et al., 2001; Mundim et al., 2008; Spolidorio et al., 2009; Miranda et al., 2014) and from 3.6\% to 73\% in the central-western region (Paludo et al., 2003; Mundim et al., 2008; Ramos et al., 2015; Melo et al., 2016; Sousa et al., 2017). In addition, cases of infection by Hepatozoon spp. detected through molecular analyses were reported in the southern region (Lasta et al., 2009; Malheiros et al., 2016; Mongruel et al., 2018) and in the northern region (Gomes et al., 2016). 
The molecular tests revealed different combinations of coinfections among the dogs in Vila de Jericoacoara. Coinfections have also been reported in other studies (Santos et al., 2009; Ramos et al., 2010; Spolidorio et al., 2011) and have occurred because $B$. vogeli, $H$. canis and $E$. canis are transmitted by the same vector; i.e. the brown tick $R$. sanguineus s.l.. This result serves as a warning with regard to the consequences of coinfection, such as worsening of clinical abnormalities, and the importance of correct diagnosis, in order to be able to indicate the appropriate treatment (Rojas et al., 2014).

Our results indicated that the occurrence rate of infection by $B$. vogeli was higher among animals that were less than three years old, compared to older animals. This can be explained by the immaturity of the humoral immune system in young dogs. According to Bashir et al. (2009), these animals may not have the full capacity to produce antibodies against pathogens, although the cellular immune response also plays an important role in the immune response against this protozoan. Similar results were found by Rotondano et al. (2015). These authors observed that newly weaned young dogs were more susceptible to disease due to the stress of adapting to food and the environment. Our results also corroborate those of Paulino et al. (2018), who found that animals under five years of age were more likely to test positive for $B$. vogeli DNA.

The type of habitation of the animals living in Vila de Jericoacoara was associated with positivity for $\mathrm{H}$. canis. The occurrence rate for infection by this pathogen was higher among stray dogs than among domiciled dogs. Corroborating our findings, Aktas et al. (2015) demonstrated that stray and shelter dogs showed significantly higher prevalence of $H$. canis infection, compared with pet dogs. We can hypothesize that these dogs are more prone to infection due to greater exposure to the vector and lack of veterinary care.

In our study, no associations between clinical alterations in the dogs and infection or exposure to the pathogens studied were demonstrated. According to Mundim et al. (2008), the clinical presentation of vector-borne diseases varies according to the level of parasitemia and the animal's immune status. Moreover, $48.33 \%$ of the infected or exposed animals studied here did not present any clinical signs suggestive of tick-borne diseases, and $60.21 \%$ of the uninfected or unexposed animals presented lymphadenopathy, weight loss, anorexia, vomiting, diarrhea or fever.

It was observed in Vila de Jericoacoara that anemia was associated with infection by $H$. canis. Some changes to animals positive for $H$. canis had been previously described, including anemia, leukocytosis with neutrophilia, lymphopenia, monocytosis and thrombocytopenia (Paludo et al., 2003; Aguiar et al., 2004; Antunes et al., 2015; Mongruel et al., 2018). Regarding white blood cells, it was observed that leukopenia was associated with the presence of rickettsial antibodies. Alterations such as anemia, thrombocytopenia and moderate initial leukopenia, followed by leukocytosis, have been described in animals positive for Rickettsia spp. (Keenan et al., 1977a, b; Breitschwerdt et al., 1988; Comer, 1991). However, the hematological alterations presented by infected animals can also be caused by other pathogens and by exposure to allergens. Furthermore, our results showed that $16.6 \%$ of the infected or exposed animals had a normal hematological profile.

\section{Conclusions}

In this study, circulation of B. vogeli, H. canis and E. canis in dogs in the coastal region of the state of Ceará, northeastern Brazil, was proved. It was noteworthy that Rickettsia spp., mainly represented by $R$. amblyommatis, was also circulating among dogs in Vila de Jericoacora. As far as we know, this study provided the first evidence on circulation of these pathogens among dogs in the region analyzed. Canine active infection by $E$. canis and $B$. vogeli indicates environmental contamination by the tick vector, $R$. sanguineus S.I., which ensures occurrences of primary infection in young dogs. This study may help to elucidate the natural history of tick-borne diseases and serve as a warning regarding the need to intensify ectoparasite control among dogs, considering that they may be infected with these agents or with others that were not evaluated in this report.

\section{Acknowledgements}

The authors would like to thank to Fundação Cearense de Amparo à Pesquisa (FUNCAP) for a scholarship; Coordenação de Aperfeiçoamento de Pesssoal de Nível Superior (CAPES), Fundação de Amparo à Pesquisa do Estado de São Paulo (FAPESP) and Prefeitura Municipal de Jijoca de Jericoacoara for financial support to this project; PARNA of Jericoacoara for support in the village; and UNINTA and the association "Jeri sobre Patas" for organizing the castration campaign. 


\section{References}

Aguiar DM, Ribeiro MG, Silva WB, Dias JG Jr, Megid JJ, Paes AC. Hepatozoonose canina: achados clínico-epidemiológicos em três casos. Arq Bras Med Vet Zootec 2004; 56(3): 411-413. http://dx.doi.org/10.1590/S0102-09352004000300021.

Aktas M, Özübek S, Altay K, Balkaya I, Utuk AE, Kırbas A, et al. A molecular and parasitological survey of Hepatozoon canis in domestic dogs in Turkey. Vet Parasito/ 2015; 209(3-4): 264-267. http://dx.doi.org/10.1016/j.vetpar.2015.02.015. PMid:25771934.

Almeida AP, Marcili A, Leite RC, Nieri-Bastos FA, Domingues LN, Martins JR, et al. Coxiella symbiont in the tick Ornithodoros rostratus (Acari: argasidae). Ticks Tick Borne Dis 2012; 3(4): 203-206. http://dx.doi.org/10.1016/j.ttbdis.2012.02.003. PMid:22480930.

Altschul SF, Gish W, Miller W, Myers EW, Lipman DJ. Basic local alignment search tool. J Mol Biol 1990; 215(3): 403-410. http:// dx.doi.org/10.1016/S0022-2836(05)80360-2. PMid:2231712.

Antunes TR, Valençoela RA, Sorgatto S, Oliveira BB, da Silva Godoy KC, de Souza Al. Aspectos hematológicos de cães naturalmente infectados por Hepatozoon sp. no município de Campo Grande, MS, Brasil. Acta Vet Bras 2015; 9(3): $234-238$.

Apperson CS, Engber B, Nicholson WL, Mead DG, Engel J, Yabsley MJ, et al. Tick-borne diseases in North Carolina: is "Rickettsia amblyommii" a possible cause of rickettsiosis reported as Rocky Mountain spotted fever? Vector Borne Zoonotic Dis 2008; 8(5): 597-606. http://dx.doi.org/10.1089/vbz.2007.0271. PMid:18447622.

Baneth G. Perspectives on canine and feline hepatozoonosis. Vet Parasitol 2011; 181(1): 3-11. http://dx.doi.org/10.1016/j. vetpar.2011.04.015. PMid:21620568.

Barrett A, Little SE, Shaw E. "Rickettsia amblyommii" and R. montanensis infection in dogs following natural exposure to ticks. Vector Borne Zoonotic Dis 2014; 14(1): 20-25. http://dx.doi.org/10.1089/vbz.2013.1325. PMid:24359419.

Barros-Battesti DM, Arzua M, Bechara GH. Carrapatos de importância médico-veterinária da região Neotropical: um guia ilustrado para identificação de espécies. São Paulo: International Consortium on Ticks and Tick-borne Diseases/Butantan; 2006.

Bashir IN, Chaudhry ZI, Ahmed S, Saeed MA. Epidemiological and vector identification studies on canine babesiosis. Pak Vet J 2009; 29(2): 51-54.

Bernardino MGS, Meireles MVN, Silva EG, Xavier FJR, Satake F. Prevalência de hepatozoonose canina no município de Areia, Paraíba, Brasil. Biotemas 2016; 29(1): 175-179. http://dx.doi.org/10.5007/2175-7925.2016v29n1p175.

Braga JFV, Souza FAL, Silva LS, Fonseca LS, Pinho FA, Fotoran WL, et al. Molecular, serological, and parasitological detection of Babesia vogeli in dogs in the state of Piauí, Brazil. Semina: Ciênc Agrár 2019;40(6 Suppl. 2): 3035-3044. http://dx.doi.org/10.5433/16790359.2019v40n6Supl2p3035.

Breitschwerdt EB, Walker DH, Levy MG, Burgdorfer W, Corbett WT, Hurlbert SA, et al. Clinical, hematologic, and humoral immune response in female dogs inoculated with Rickettsia rickettsii and Rickettsia montana. Am J Vet Res 1988; 49(1): 70-76. PMid:3128147.

Chomel B. Tick-borne infections in dogs: an emerging infectious threat. Vet Parasitol 2011; 179(4): 294-301. http://dx.doi. org/10.1016/j.vetpar.2011.03.040. PMid:21777730.

Comer KM. Rocky Mountain spotted fever. Vet Clin North Am Small Anim Pract 1991; 21(1): 27-44. http://dx.doi.org/10.1016/ S0195-5616(91)50002-4. PMid:2014623.

Costa AP, Costa FB, Labruna MB, Silveira I, Moraes-Filho J, Soares JF, et al. A serological and molecular survey of Babesia vogeli, Ehrlichia canis and Rickettsia spp. among dogs in the state of Maranhão, northeastern Brazil. Rev Bras Parasitol Vet 2015; 24(1): 28-35. http://dx.doi.org/10.1590/S1984-29612015008. PMid:25909250.

Costa FB, Costa AP, Moraes-Filho J, Martins TF, Soares HS, Ramirez DG, et al. Rickettsia amblyommatis infecting ticks and exposure of domestic dogs to Rickettsia spp. in an Amazon-Cerrado transition region of northeastern Brazil. PLoS One 2017; 12(6): e0179163. http://dx.doi.org/10.1371/journal.pone.0179163. PMid:28594882.

Dantas-Torres F, Silva YY, Miranda DEO, Sales KGS, Figueredo LA, Otranto D. Ehrlichia spp. infection in rural dogs from remote indigenous villages in north-eastern Brazil. Parasit Vectors 2018; 11(1): 139. http://dx.doi.org/10.1186/s13071-018-2738-3. PMid:29554954.

Doyle CK, Labruna MB, Breitschwerdt EB, Tang YW, Corstvet RE, Hegarty BC, et al. Detection of medically important Ehrlichia by quantitative multicolor TaqMan real-time polymerase chain reaction of the dsb gene. J Mol Diagn 2005; 7(4): 504-510. http:// dx.doi.org/10.1016/S1525-1578(10)60581-8. PMid:16237220.

Dubie TR, Grantham R, Coburn L, Noden BH. Pictorial key for identification of immature stages of common ixodid ticks found in pastures in Oklahoma. Southwest Entomo/ 2017; 42(1): 1-14. http://dx.doi.org/10.3958/059.042.0101.

Figueredo LA, Sales KGDS, Deuster K, Pollmeier M, Otranto D, Dantas-Torres F. Exposure to vector-borne pathogens in privately owned dogs living in different socioeconomic settings in Brazil. Vet Parasitol 2017; 243: 18-23. http://dx.doi.org/10.1016/j. vetpar.2017.05.020. PMid:28807290. 
Gomes LA, Moraes PH, Nascimento LC, O'Dwyer LH, Nunes MR, Rossi AD, et al. Molecular analysis reveals the diversity of Hepatozoon species naturally infecting domestic dogs in a northern region of Brazil. Ticks Tick Borne Dis 2016; 7(6): 1061-1066. http://dx.doi.org/10.1016/j.ttbdis.2016.09.008. PMid:27665264.

Han BA, Kramer AM, Drake JM. Global patterns of zoonotic disease in mammals. Trends Parasito/ 2016; 32(7): 565-577. http:// dx.doi.org/10.1016/j.pt.2016.04.007. PMid:27316904.

Instituto Chico Mendes de Conservação da Biodiversidade - ICMBio. Parque Nacional de Jericoacoara [online]. 2021 [cited 2021 Mar 22]. Available from: https://www.icmbio.gov.br/portal/visitacao1/unidades-abertas-a-visitacao/190-parque-nacional-dejericoacoara.html

Keenan KP, Buhles WC Jr, Huxsoll DL, Williams RG, Hildebrandt PK. Studies on the pathogenesis of Rickettsia rickettsii in the dog: clinical and clinicopathologic changes of experimental infection. Am J Vet Res 1977a; 38(6): 851-856. PMid:879582.

Keenan KP, Ruhles WC Jr, Huxsoll DL, Williams RG, Hildebrandt PK, Campbell JM, et al. Pathogenesis of infection with Rickettsia rickettsii in the dog: a disease model for Rocky Mountain spotted fever.J Infect Dis 1977b; 135(6): 911-917. http://dx.doi.org/10.1093/ infdis/135.6.911. PMid:405432.

Labruna MB, Horta MC, Aguiar DM, Cavalcante GT, Pinter A, Gennari SM, et al. Prevalence of Rickettsia infection in dogs from the urban and rural areas of Monte Negro Municipality, western Amazon, Brazil. Vector Borne Zoonotic Dis 2007; 7(2): 249-255. http://dx.doi.org/10.1089/vbz.2006.0621. PMid:17627445.

Labruna MB, Kamakura O, Moraes-Filho J, Horta MC, Pacheco RC. Rocky Mountain spotted fever in dogs, Brazil. Emerg Infect Dis 2009; 15(3): 458-460. http://dx.doi.org/10.3201/eid1503.081227. PMid:19239764.

Lasta CS, Santos AP, Mello FPS, Lacerda LA, Messick JB, Díaz González FH. Infecção por Hepatozoon canis em canino doméstico na região Sul do Brasil confirmada por técnicas moleculares. Cienc Rural 2009; 39(7): 2135-2140. http://dx.doi.org/10.1590/ S0103-84782009005000160.

Linardi PM, Guimarães LR. Sifonápteros do Brasil. São Paulo: Museu de Zoologia USP/FAPESP; 2000.

Lopes MG, Krawczak FS, Lima JTR, Fournier GFSR, Acosta ICL, Ramirez DG, et al. Occurrence of Ehrlichia canis and Hepatozoon canis and probable exposure to Rickettsia amblyommatis in dogs and cats in Natal, RN. Rev Bras Parasito/ Vet 2019; 28(1): $151-156$. http://dx.doi.org/10.1590/s1984-296120180065. PMid:30462820.

Lugarini C, Martins TF, Ogrzewalska M, Vasconcelos NCT, Ellis VA, Oliveira JB, et al. Rickettsial agents in avian ixodid ticks in northeast Brazil. Ticks Tick Borne Dis 2015; 6(3): 364-375. http://dx.doi.org/10.1016/j.ttbdis.2015.02.011. PMid:25800099.

Malheiros J, Costa MM, do Amaral RB, de Sousa KCM, André MR, Machado RZ, et al. Identification of vector-borne pathogens in dogs and cats from Southern Brazil. Ticks Tick Borne Dis 2016; 7(5): 893-900. http://dx.doi.org/10.1016/j.ttbdis.2016.04.007. PMid:27266811.

McIntosh D, Bezerra RA, Luz HR, Faccini JLH, Gaiotto FA, Giné GAF, et al. Detection of Rickettsia bellii and Rickettsia amblyommii in Amblyomma longirostre (Acari: Ixodidae) from Bahia state, northeast Brazil. Braz J Microbiol 2015; 46(3): 879-883. http://dx.doi. org/10.1590/S1517-838246320140623. PMid:26413074.

Melo ALT, Witter R, Martins TF, Pacheco TA, Alves AS, Chitarra CS, et al. A survey of tick-borne pathogens in dogs and their ticks in the Pantanal biome, Brazil. Med Vet Entomol 2016; 30(1): 112-116. http://dx.doi.org/10.1111/mve.12139. PMid:26467462.

Miranda RL, O'Dwyer LH, de Castro JR, Metzger B, Rubini AS, Mundim AV, et al. Prevalence and molecular characterization of Hepatozoon canis in dogs from urban and rural areas in Southeast Brazil. Res Vet Sci 2014; 97(2): 325-328. http://dx.doi. org/10.1016/j.rvsc.2014.06.015. PMid:25039064.

Mongruel ACB, Ikeda P, Sousa KCM, Benevenute JL, Falbo MK, Machado RZ, et al. Molecular detection of vector borne pathogens in anemic and thrombocytopenic dogs in southern Brazil. Rev Bras Parasito/ Vet 2018; 27(4): 505-513. http://dx.doi.org/10.1590/ s1984-296120180069. PMid:30462822.

Moraes-Filho J, Krawczak FS, Costa FB, Soares JF, Labruna MB. Comparative evaluation of the vector competence of four South American populations of the Rhipicephalus sanguineus group for the bacterium Ehrlichia canis, the agent of canine monocytic ehrlichiosis. PLoS One 2015; 10(9): e0139386. http://dx.doi.org/10.1371/journal.pone.0139386. PMid:26414283.

Moreira SM, Bastos CV, Araújo RB, Santos M, Passos LMF. Retrospective study (1998-2001) on canine ehrlichiosis in Belo Horizonte, MG, Brazil. Arq Bras Med Vet Zootec 2003; 55(2): 141-147. http://dx.doi.org/10.1590/S0102-09352003000200003.

Mundim AV, Morais IA, Tavares M, Cury MC, Mundim MJ. Clinical and hematological signs associated with dogs naturally infected by Hepatozoon sp. and with other hematozoa: a retrospective study in Uberlândia, Minas Gerais, Brazil. Vet Parasitol 2008; 153(1 2): 3-8. http://dx.doi.org/10.1016/j.vetpar.2008.01.018. PMid:18304739.

O'Dwyer LH, Massard CL, Pereira de Souza JC. Hepatozoon canis infection associated with dog ticks of rural areas of Rio de Janeiro State, Brazil. Vet Parasito/ 2001; 94(3): 143-150. http://dx.doi.org/10.1016/S0304-4017(00)00378-2. PMid:11113545. 
Ogrzewalska M, Uezu A, Labruna MB. Ticks (Acari: Ixodidae) infesting wild birds in the Atlantic Forest in northeastern Brazil, with notes on rickettsial infection in ticks. Parasitol Res 2011; 108(3): 665-670. http://dx.doi.org/10.1007/s00436-010-2111-8. PMid:20953629.

Oliveira GMB, da Silva IWG, Evaristo AMCF, Serpa MCA, Campos ANS, Dutra V, et al. Tick-borne pathogens in dogs, wild small mammals and their ectoparasites in the semi-arid Caatinga biome, northeastern Brazil. Ticks Tick Borne Dis 2020; 11 (4): 101409. http://dx.doi.org/10.1016/j.ttbdis.2020.101409. PMid:32111546.

Oliveira SV, Guimarães JN, Reckziegel GC, Neves BMC, Araújo-Vilges KM, Fonseca LX, et al. An update on the epidemiological situation of spotted fever in Brazil. J Venom Anim Toxins Incl Trop Dis 2016; 22(1): 22. http://dx.doi.org/10.1186/s40409-016-00774. PMid:27555867.

Paludo GR, Dell'Porto A, Castro e Trindade AR, McManus C, Friedman H. Hepatozoon spp.: report of some cases in dogs in Brasília, Brazil. Vet Parasitol 2003; 118(3-4): 243-248. http://dx.doi.org/10.1016/j.vetpar.2003.10.009. PMid:14729172.

Paulino PG, Pires MS, da Silva CB, Peckle M, da Costa RL, Vitari GL, et al. Molecular epidemiology of Babesia vogeli in dogs from the southeastern region of Rio de Janeiro, Brazil. Vet Parasitol Reg Stud Rep 2018; 13: 160-165. http://dx.doi.org/10.1016/j. vprsr.2018.06.004. PMid:31014866.

Peleg O, Baneth G, Eyal O, Inbar J, Harrus S. Multiplex real-time qPCR for the detection of Ehrlichia canis and Babesia canis vogeli. Vet Parasitol 2010; 173(3-4): 292-299. http://dx.doi.org/10.1016/j.vetpar.2010.06.039. PMid:20674177.

Ramos CAN, Babo-Terra VJ, Pedroso TC, Souza AF Fo, Araújo FR, Cleveland HPK. Molecular identification of Hepatozoon canis in dogs from Campo Grande, Mato Grosso do Sul, Brazil. Rev Bras Parasito/ Vet 2015; 24(2): 247-250. http://dx.doi.org/10.1590/ S1984-29612015019. PMid:26154969.

Ramos R, Ramos C, Araújo F, Oliveira R, Souza I, Pimentel D, et al. Molecular survey and genetic characterization of tick-borne pathogens in dogs in metropolitan Recife (north-eastern Brazil). Parasitol Res 2010; 107(5): 1115-1120. http://dx.doi.org/10.1007/ s00436-010-1979-7. PMid:20680344.

Robinson MT, Satjanadumrong J, Hughes T, Stenos J, Blacksell SD. Diagnosis of spotted fever group Rickettsia infections: the Asian perspective. Epidemiol Infect 2019; 147: e286. http://dx.doi.org/10.1017/S0950268819001390. PMid:31587667.

Rojas A, Rojas D, Montenegro VM, Gutiérrez R, Yasur-Landau D, Baneth G. Vector-borne pathogens in dogs from Costa Rica: first molecular description of Babesia vogeli and Hepatozoon canis infections with a high prevalence of monocytic ehrlichiosis and the manifestations of co-infection. Vet Parasitol 2014; 199(3-4): 121-128. http://dx.doi.org/10.1016/j.vetpar.2013.10.027. PMid:24315693.

Rotondano T, Almeida HK, Krawczak FS, Santana VL, Vidal IF, Labruna MB, et al. Survey of Ehrlichia canis, Babesia spp. and Hepatozoon spp. in dogs from a semiarid region of Brazil. Rev Bras Parasitol Vet 2015; 24(1): 52-58. http://dx.doi.org/10.1590/ S1984-29612015011. PMid:25909253.

Rotondano T, Krawczak F, Barbosa W, Moraes-Filho J, Bastos F, Labruna M, et al. Ehrlichia canis and Rickettsia spp. in dogs from urban areas in Paraiba state, northeastern Brazil. Rev Bras Parasitol Vet 2017; 26(2): 211-215. http://dx.doi.org/10.1590/s198429612017030. PMid:28658415.

Saito TB, Larsson CE, Labruna MB, Cunha-Filho NA, Pacheco RC, Ferreira F, et al. Canine infection by Rickettsiae and Ehrlichiae in southern Brazil. Am J Trop Med Hyg 2008; 79(1): 102-108. http://dx.doi.org/10.4269/ajtmh.2008.79.102. PMid:18606772.

Santos F, Coppede JS, Pereira AL, Oliveira LP, Roberto PG, Benedetti RB, et al. Molecular evaluation of the incidence of Ehrlichia canis, Anaplasma platys and Babesia spp. in dogs from Ribeirão Preto, Brazil. Vet J 2009; 179(1): 145-148. http://dx.doi.org/10.1016/j. tvjl.2007.08.017. PMid:17920967.

Saraiva DG, Nieri-Bastos FA, Horta MC, Soares HS, Nicola PA, Pereira LCM, et al. Rickettsia amblyommii infecting Amblyomma auricularium ticks in Pernambuco, northeastern Brazil: isolation, transovarial transmission, and transstadial perpetuation. Vector Borne Zoonotic Dis 2013; 13(9): 615-618. http://dx.doi.org/10.1089/vbz.2012.1223. PMid:23705586.

Schnittger L, Rodriguez AE, Florin-Christensen M, Morrison DA. Babesia: a world emerging. Infect Genet Evol 2012; 12(8): 17881809. http://dx.doi.org/10.1016/j.meegid.2012.07.004. PMid:22871652.

Shaw SE, Day MJ, Birtles RJ, Breitschwerdt EB. Tick-borne infectious diseases of dogs. Trends Parasito/ 2001; 17(2): 74-80. http:// dx.doi.org/10.1016/S1471-4922(00)01856-0. PMid:11228013.

Silva AB, Cardoso KM, Oliveira SV, Costa RMF, Oliveira G, Amorim M, et al. Rickettsia amblyommatis infecting Amblyomma pseudoconcolor in area of new focus of spotted fever in northeast Brazil. Acta Trop 2018; 182: 305-308. http://dx.doi.org/10.1016/j. actatropica.2018.03.005. PMid:29545159.

Silva AB, Costa AP, Sá JC, Costa FB, Santos ACG, Guerra RMSNC. Detecção molecular de Babesia canis vogeli em cães e em Rhipicephalus sanguineus na mesorregião do oeste maranhense, nordeste brasileiro. Cienc Anim Bras 2012; 13(3): 388-395. http:// dx.doi.org/10.5216/cab.v13i3.18439. 
Silva VCL, Lima ER, Dias MBMC, Fukahori FLP, Rego MSA, Pinheiro JW Jr, et al. Parasitological and molecular detection of Babesia canis vogeli in dogs of Recife, Pernambuco and evaluation of risk factors associated. Semina: Ciênc Agrár 2016; 37(1): $163-172$. http://dx.doi.org/10.5433/1679-0359.2016v37n1p163.

Sousa KCM, Fernandes MP, Herrera HM, Benevenute JL, Santos FM, Rocha FL, et al. Molecular detection of Hepatozoon spp. in domestic dogs and wild mammals in southern Pantanal, Brazil with implications in the transmission route. Vet Parasito/ 2017; 237: 37-46. http://dx.doi.org/10.1016/j.vetpar.2017.02.023. PMid:28291601.

Spolidorio MG, Labruna MB, Zago AM, Donatele DM, Caliari KM, Yoshinari NH. Hepatozoon canis infecting dogs in the State of Espírito Santo, southeastern Brazil. Vet Parasitol 2009; 163(4): 357-361. http://dx.doi.org/10.1016/j.vetpar.2009.05.002. PMid:19482427.

Spolidorio MG, Torres MDM, Campos WNS, Melo ALT, Igarashi M, Amude AM, et al. Molecular detection of Hepatozoon canis and Babesia canis vogeli in domestic dogs from Cuiabá, Brazil. Rev Bras Parasitol Vet 2011; 20(3): 253-255. http://dx.doi.org/10.1590/ S1984-29612011000300015. PMid:21961759.

Steuber S, Abdel-Rady A, Clausen P. PCR-RFLP analysis: a promising technique for host species identification of blood meals from tsetse flies (Diptera: Glossinidae). Parasitol Res 2005; 97(3): 247-254. http://dx.doi.org/10.1007/s00436-005-1410-y. PMid:15999278.

Tanikawa A, Labruna MB, Costa A, Aguiar DM, Justiniano SV, Mendes RS, et al. Ehrlichia canis in dogs in a semiarid region of Northeastern Brazil: Serology, molecular detection and associated factors. Res Vet Sci 2013; 94(3): 474-477. http://dx.doi. org/10.1016/j.rvsc.2012.10.007. PMid:23141416.

Vieira RFC, Biondo AW, Guimarães AMS, Santos AP, Santos RP, Dutra LH, et al. Ehrlichiosis in Brazil. Rev Bras Parasitol Vet 2011; 20(1): 1-12. http://dx.doi.org/10.1590/S1984-29612011000100002. PMid:21439224. 